\title{
PENGARUH PEMBERIAN IKAN TERI (Engraulis encrasicolus) TERHADAP KADAR $C$ - REACTIVE PROTEIN (CRP) TIKUS SPRAGUE DAWLEY USIA SATU BULAN
}

\author{
Nadia Savitri, Niken Puruhita*) \\ Program Studi Ilmu Gizi Fakultas Kedokteran Universitas Diponegoro \\ Jl.Dr.Sutomo No.18, Semarang, Telp (024) 8453708, Email : gizifk@ undip.ac.id
}

\begin{abstract}
Background: $C$-reactive protein $(C R P)$ is an inflamation marker which is a reliable predictor for Cardiovascular disease (CVD). The increase of CRP level is corelated with higher risk of CVD. Omega-3 fatty acids has been known as anti-inflamatory agent and thus possess protective effect of CVD. CRP also related to index omega-3 as a predictor of dietary omega-3 intake. Low level of omega-3 intake also known lead to higher risk of CVD. Black sea anchovy (Engraulis encrasicolus) contains high level of Omega-3 fatty acids which possible to reduce the level of CRP. This study was conducted to analyze the effect of high omega-3 diet from dietary black sea anchovy on CRP levels of healthy rats.

Methode: True experimental with post test only with control group design using 14 Sprague dawley rats which were randomly allocated into two groups; control and anchovy. Subject has been given $1.5 \mathrm{~g}$ anchovy for $200 \mathrm{gr}$ that mixed in their food for 19 days. Blood sample collected from plexus retro orbitalis and CRP levels analyzed from serum using Quantitave-CRP. Data was analyzed using descriptive methods.

Result: CRP levels for both control and anchovy group categorized as a normal level of CRP $(<5 \mathrm{mg} / \mathrm{L})$.

Conclusion: Data gathered in this study can not be used to describe the mechanism of CVD protective effect given by dietary anchovy related to CRP levels.

Keywords : Black sea anchovy; CRP level; cardiovascular disease
\end{abstract}

\section{ABSTRAK}

Latar Belakang: C-reactive protein (CRP), adalah marker inflamasi yang merupakan prediktor kuat kejadian penyakit kardiovaskuler (PKV). Peningkatan kadar CRP berkaitan dengan peningkatan risiko PKV. Asam lemak omega-3 diketahui memiliki sifat-sifat anti inflamasi sehingga asam lemak omega-3 dipercaya memiliki efek protektif terhadap PKV. CRP juga berkaitan dengan indeks omega-3 sebagai prediktor asupan omega-3. Kadar indeks omega3 yang rendah diketahui meningkatkan risiko PKV. Ikan teri (Engraulis encrasicolus) mengandung asam lemak omega-3 yang tinggi yang dimungkinkan dapat menurunkan kadar CRP. Penelitian ini bertujuan untuk mengetahui pengaruh pemberian ikan teri kadar CRP tikus.

Metode: Penelitian eksperimental murni dengan post test only with control group design yang diterapkan pada 14 tikus Sprague dawley usia 1 bulan yang dikelompokkan menggunakan sistem acak sederhana menjadi 1 kelompok kontrol dan 1 kelompok intervensi. Subjek diberikan pakan modifikasi dengan penambahan ikan teri sebanyak $1.5 \mathrm{gr}$ per 10 gr pakan selama 19 hari. Sampel darah diambil dari plexus retro orbitalis dan pengukuran kadar CRP dari serum ditentukan menggunakan metode CRP kuantitatif. Data dianalisis dengan analisa data deskriptif.

Hasil: Kadar CRP pada kedua kelompok, kontrol dan perlakuan adalah sama yaitu dalam batas $<5 \mathrm{mg} / \mathrm{L}$ yang termasuk dalam kategori normal.

Kesimpulan: Data yang diperoleh pada penelitian ini tidak dapat digunakan untuk menjelaskan mekanisme protektif PKV dari diet tinggi asam lemak omega-3 yang berasal dari ikan teri terhadap kadar CRP tikus sehat

Kata kunci : ikan teri; kadar CRP; penyakit kardiovaskuler

\section{PENDAHULUAN}

$C$-reactive protein (CRP), marker dari inflamasi adalah prediktor kuat kejadian penyakit kardiovaskuler (PKV). Sejak ditemukan bahwa orang dengan kadar lipid normal masih mungkin menderita PKV, CRP dipertimbangkan sebagai faktor risiko independen PKV. ${ }^{\mathbf{1 , 2}}$ Secara umum, PKV disebabkan oleh 2 faktor utama, yaitu atherosklerosis dan inflamasi. Inflamasi dipercaya menjadi penyebab utama dan awal terjadinya PKV. CRP sebagai marker inflamasi terlibat secara langsung pada atherosklerosis, dan peningkatan kadar CRP berkaitan dengan peningkatan risiko
PKV. ${ }^{3}$ American Heart Association (AHA) menyebutkan kategori risiko relatif PKV berdasarkan kadar CRP adalah rendah apabila $<1.0$ $\mathrm{mg} / \mathrm{L}$, sedang apabila $1.0-3.0 \mathrm{mg} / \mathrm{L}$, dan tinggi apabila $>3.0 \mathrm{mg} / \mathrm{L} .^{4}$

Asam lemak omega-3 diketahui memiliki sifat-sifat anti inflamasi dan anti oksidan sehingga asam lemak omega-3 dipercaya memiliki efek protektif terhadap PKV karena sifat-sifat tersebut. Penelitian terdahulu mengatakan kadar asam lemak omega-3 darah memiliki kaitan yang berbanding terbalik dengan kadar CRP pada kelompok dewasa sehat. ${ }^{5}$ Penelitian lain menunjukkan, subjek dengan

\footnotetext{
${ }^{*}$ Penulis Penanggungjawab
} 
kadar CRP > $3.0 \mathrm{mg} / \mathrm{L}$ yang diberikan diet tinggi asam lemak omega-3 selama 8 minggu, mengalami penurunan kadar CRP yang signifikan. ${ }^{6}$

Ikan teri (Engraulis encraicolus) merupakan salah satu bahan pangan yang tinggi asam lemak omega-3 dan tergolong dalam oily fish. Ikan teri (Engraulis encraicolus) memiliki kandungan $1,4 \mathrm{~g}$ asam lemak omega-3 per 100 gram jaringan atau bagian yang dapat dimakan, dengan komposisi 0,5 g EPA dan 0,9 g DHA. ${ }^{7}$ Kelebihan lainnya adalah ikan teri banyak dijumpai di Indonesia, diketahui dari jumlah produksi teri Indonesia berada di urutan ke-8 dunia. ${ }^{8}$

Ikan teri dimungkinkan dapat menjadi alternatif sumber alami untuk mencukupi kebutuhan asam lemak omega-3 harian sehingga dapat mencegah terjadinya PKV dengan menurunkan kadar CRP tanpa efek samping. Pemberian ikan teri sebanyak $1.5 \mathrm{~g}$ per hari yang didapatkan dari konversi rekomendasi asupan asam lemak omega-3 harian pada manusia ke tikus yang kemudian dicampurkan pada $200 \mathrm{~g}$ pakan diharapkan dapat menurunkan kadar CRP tikus Sprague Dawley usia satu bulan.

Subjek penelitian ini menggunakan tikus Sprague dawley karena memiliki kemiripan genetika dan karakter dengan manusia, serta memiliki tingkat adaptasi yang baik terhadap uji yang diberikan. ${ }^{9}$ Penelitian ini bertujuan untuk mengetahui pengaruh pemberian ikan teri (Engraulis encrasicolus) terhadap kadar CRP tikus Sprague dawley usia satu bulan.

\section{METODE}

\section{Subjek Penelitian}

Subjek yang digunakan pada penelitian ini adalah tikus Sprague dawley berusia satu bulan dengan berat badan 40-60 gram yang diperoleh dari LPPT UNIT IV Universitas Gadjah Mada
Yogyakarta. Pemeliharaan hewan coba juga dilakukan di LPPT UNIT IV Universitas Gadjah Mada Yogyakarta.

\section{Bahan}

Bahan yang digunakan selama penelitian berlangsung meliputi pakan standar dan pakan ikan teri. Pakan standar yang digunakan adalah jenis BR 2 (Broiler Finisher) Comfeed, sedangkan pakan ikan teri adalah pakan standar yang telah dimodifikasi, yaitu dengan mengganti komposisi pada bagian bahan sumber omega-3 dengan ikan teri segar. Pembuatan pakan standar dan pakan ikan teri dilakukan di LPPT UNIT IV Universitas Gadjah Mada Yogyakarta.

\section{Metode Penelitian}

Penelitian ini menggunakan rancangan true experiment dengan post test only with control groups design. Variabel bebas adalah pemberian ikan teri, sedangkan variabel terikat adalah kadar CRP tikus. Pemilihan subjek penelitian untuk pengelompokan dan perlakuan yang diberikan menggunakan sistem randomly allocation. Subjek penelitian dibagi menjadi 2 kelompok dengan keterangan sebagai berikut

K : Kelompok Kontrol; diberikan pakan standar

P : Kelompok Perlakuan; diberikan pakan ikan teri

Setiap kelompok memiliki jumlah subjek yang ditentukan berdasarkan ketentuan WHO dengan jumlah sampel minimal 5 ekor tikus per kelompok. Kemudian ditambahkan 25\% drop out sampel untuk antisipasi apabila terdapat tikus yang mati selama adaptasi maupun perlakuan. Maka, jumlah sampel keseluruhan dalam penelitian ini adalah 14 ekor tikus.

Tahapan Penelitian

Penelitian dilaksanakan dalam beberapa tahap yang dapat dilihat dalam gambar berikut ini

14 tikus Sprague dawley usia 1 bulan dengan rentang berat badan 40-60 gram

[aklimatisasi pakan standar dan lingkungan 7 hari]

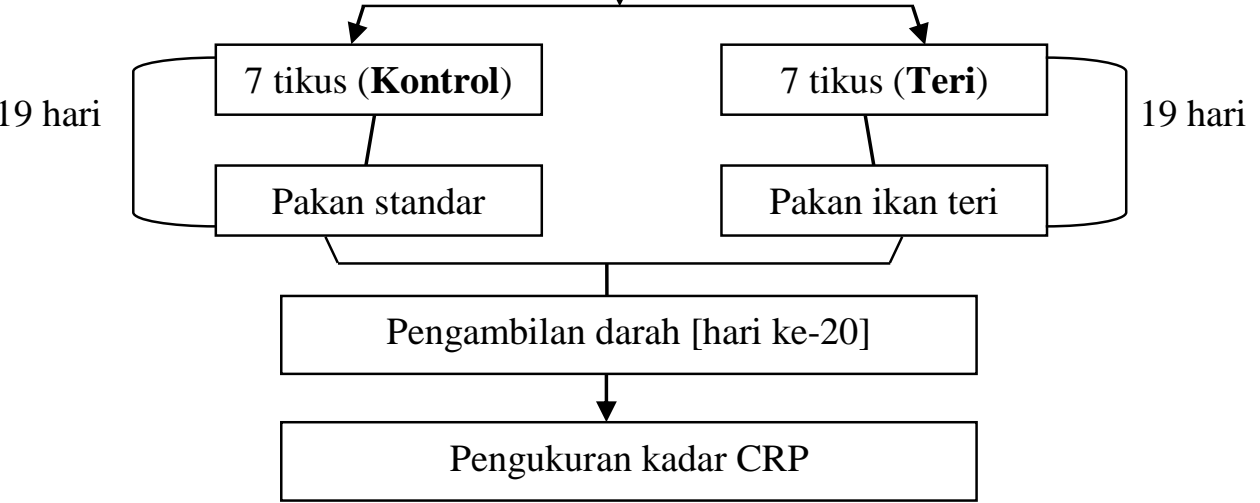

Gambar 1. Bagan Alur Kerja Penelitian 
Seluruh subjek penelitian dipelihara di kandang individual dan diberi pakan standar sebanyak 2-3 g serta air minum ad libitum. Masingmasing subjek sudah dikelompokkan sebelum aklimatisasi. Aklimatisasi dilakukan selama 7 hari. Selanjutnya subjek diberikan pakan standar untuk kelompok kontrol dan pakan ikan teri untuk kelompok perlakuan. Masing - masing pakan diberikan satu kali sehari selama 19 hari. Pada hari ke-20 dilakukan pengambilan darah untuk mengetahui kadar CRP tikus.

Pembuatan pakan standar dilakukan dengan mencampurkan semua komposisi pakan hingga tercampur rata. Sedangkan pakan ikan teri dibuat dengan memodifikasi komposisi pakan pada bagian bahan sumber omega-3 pakan standar. Ikan teri sebanyak 1.5 gram mengandung $20 \mathrm{mg}$ omega-3. Dilakukan penyetaraan pada komponen zat gizi lain sehingga menghasilkan pakan yang isokalori pada kedua jenis pakan. Ikan teri segar yang disimpan dalam kondisi beku dilelehkan dengan air mengalir, kemudian dicuci. Selanjutnya ikan teri dihaluskan hingga menjadi padatan halus, kemudian dicampurkan pada pakan standar tikus tanpa minyak kedelai.

Komposisi pakan standar dan pakan ikan teri dapat dilihat pada tabel 1.

Tabel 1. Komposisi Pakan Standar dan Pakan Ikan Teri

\begin{tabular}{ccc}
\hline Bahan & Standar $(\mathbf{g r a m} / \mathbf{K g})$ & Teri $(\mathbf{g r a m} / \mathbf{K g})$ \\
\hline Tepung Jagung & 620,692 & 617,692 \\
Kasein & 180 & 150 \\
Sukrosa & 100 & 100 \\
Serat & 50 & 50 \\
Campuran Mineral & 35 & 35 \\
Campuran Vitamin & 10 & 10 \\
L-sistin & 1,8 & 1,8 \\
Kolin bitarbat & 2,5 & 2,5 \\
TBHQ & 0,008 & 0,008 \\
Minyak Kedelai & 14,9 & 0 \\
Ikan Teri & 0 & 150 \\
Minyak Kelapa & 4.2 & 4.2 \\
\hline
\end{tabular}

Pengambilan darah tikus dilakukan melalui plexus retro orbitalis dengan pipa kapiler sebanyak $\pm 1.5 \mathrm{~mL}$. Sebelum dilakukan pengambilan darah, tikus dianastesi menggunakan ketamine dengan dosis $0.1 \mathrm{~mL}$ melalui intramuscular. Darah kemudian dimasukkan ke dalam tabung bersih. Selanjutnya darah tikus disentrifuge untuk mendapatkan serumnya. Serum disimpan dalam suhu $-10^{\circ} \mathrm{C}$ hingga akan dilakukan pengukuran kadar CRP. Pengukuran kadar serum CRP ditentukan menggunakan metode CRP kuantitatif dengan hasil yang dikategorikan dalam $<5 \mathrm{mg} / \mathrm{L}$ atau $>5 \mathrm{mg} / \mathrm{L}$. Pengukuran kadar CRP dilakukan di Laboratorium Cito Yogyakarta.

Analisis Data

Data kadar CRP dianalisis secara deskriptif karena hasil yang didapatkan tidak memiliki variasi nilai. ${ }^{10}$

\section{HASIL}

\section{Perubahan Berat Badan Tikus}

Perubahan berat badan tikus Sprague dawley selama penelitian dapat dilihat pada Gambar 2.

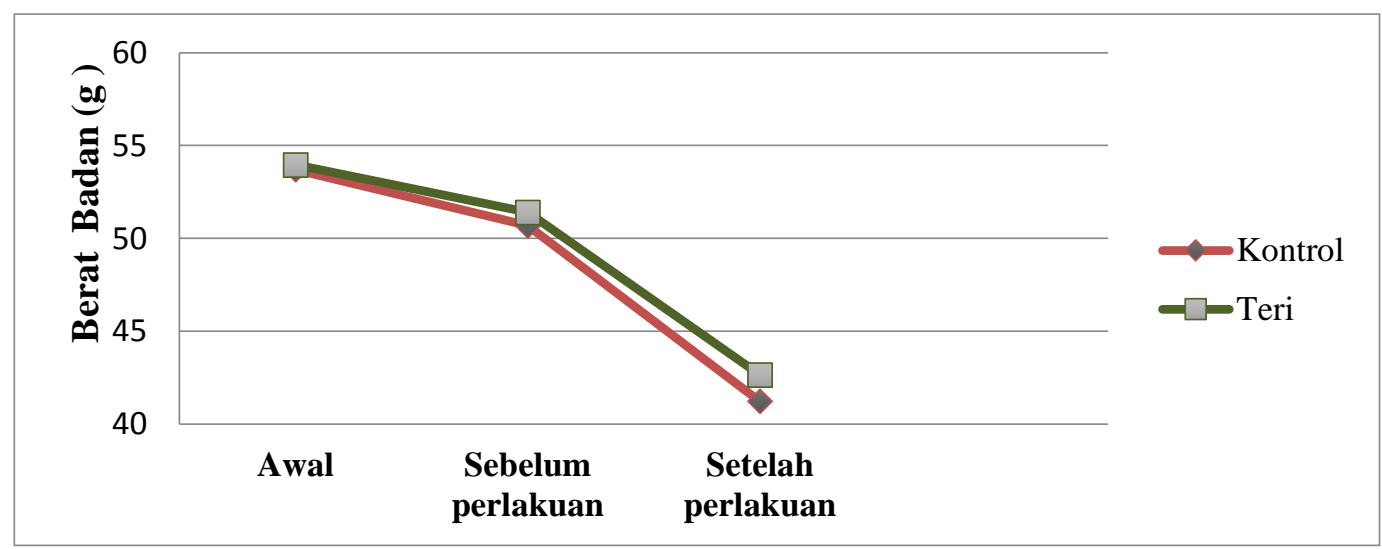

Gambar 2. Perubahan Berat Badan Tikus Sprague dawley 
Sisa Pakan Tikus
Sisa pakan tikus selama 19 hari intervensi dapat di lihat pada gambar 3 .

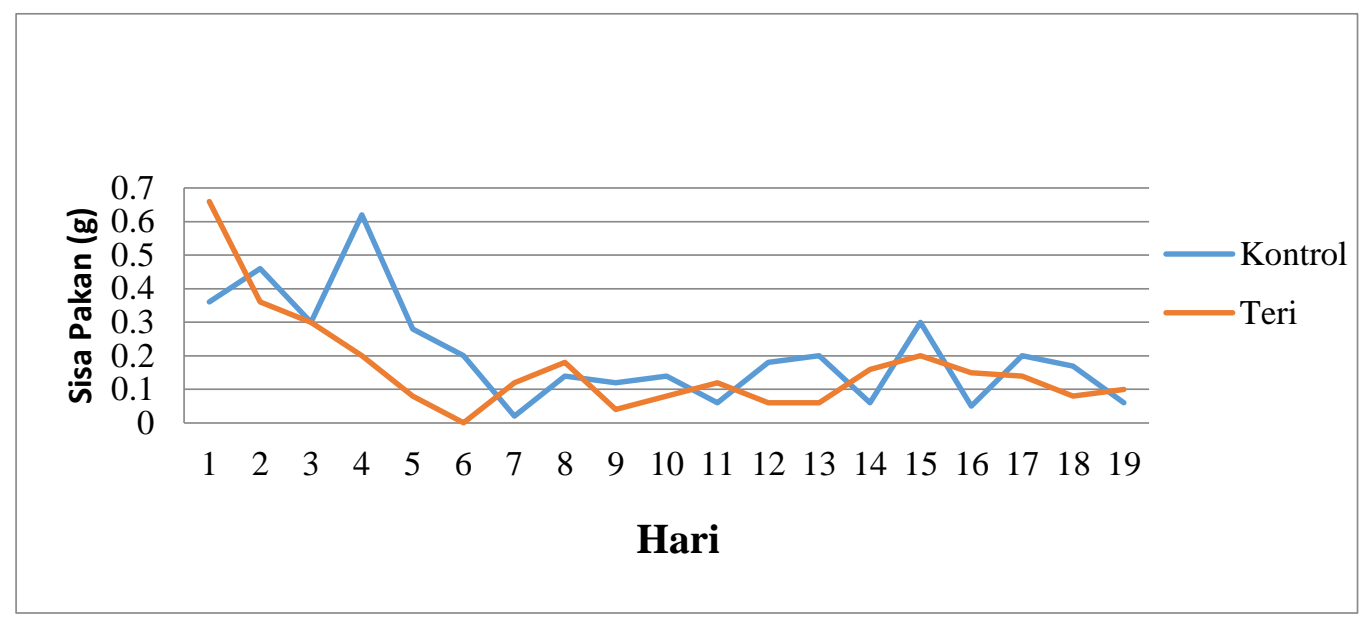

Gambar 3. Sisa Pakan Tikus Sprague dawley Selama Intervensi

\section{Kadar CRP Setelah Pemberian Pakan Standar dan Pakan Ikan Teri}

Kadar CRP tikus Sprague dawley setelah pemberian pakan ikan teri pada kelompok perlakuan dan kelompok kontrol dapat dilihat pada tabel 2.

Tabel 2. Kadar CRP Tikus Setelah Pemberian Pakan Standar Ikan Teri

\begin{tabular}{|c|c|c|}
\hline \multicolumn{2}{|c|}{ Sampel } & Kadar CRP (mg/L) \\
\hline \multirow{7}{*}{ Konrol } & K1 & $<5$ \\
\hline & $\mathrm{K} 2$ & $<5$ \\
\hline & K3 & $<5$ \\
\hline & K4 & $<5$ \\
\hline & K5 & $<5$ \\
\hline & K6 & $<5$ \\
\hline & K7 & $<5$ \\
\hline \multirow[t]{5}{*}{ Perlakuan } & $\mathrm{T} 1$ & $<5$ \\
\hline & T3 & $<5$ \\
\hline & $\mathrm{T} 4$ & $<5$ \\
\hline & T5 & $<5$ \\
\hline & $\mathrm{T} 7$ & $<5$ \\
\hline
\end{tabular}

Pada tabel 2. Terlihat bahwa seluruh sampel memiliki kadar CRP $<5 \mathrm{mg} / \mathrm{L}$ yang berarti kadar CRP masih dalam batas normal. Kadar CRP pada kelompok kontrol yang diberikan pakan standar dan pada kelompok perlakuan yang diberikan pakan ikan teri tidak menunjukkan perbedaan nilai dari hasil uji kadar CRP dengan metode CRP kuantitatif.

\section{PEMBAHASAN}

Kadar CRP Setelah Pemberian Pakan Standar dan Pakan Ikan Teri

Hasil kadar CRP yang diperoleh tidak dapat menunjukkan ada tidaknya pengaruh pemberian ikan teri (Engraulis encrasicolus) terhadap kadar CRP pada tikus Sprague dawley usia satu bulan secara statistik. Hal ini dikarenakan seluruh kadar CRP pada semua subjek sama, sehingga tidak memiliki variasi nilai untuk dianalisis secara statistik. Hasil kadar CRP yang didapatkan untuk semua subjek adalah $<5 \mathrm{mg} / \mathrm{L}$ yang termasuk dalam kategori normal menurut analisa metode CRP kuantitatif.

Apabila dianalisis secara deskriptif, hasil penelitian ini tidak menunjukkan adanya pengaruh pemberian ikan teri terhadap kadar CRP. Hasil tersebut konsisten dengan penelitian-penelitian sebelumnya. Penelitian yang mengkaji asupan asam lemak omega-3 terhadap kadar CRP menyatakan asupan asam lemak omega-3 tidak dapat menurunkan kadar CRP pada subjek yang sehat. ${ }^{11}$ 
Studi lain yang juga meneliti efek asam lemak omega-3 terhadap kadar CRP dengan hasil yang menunjukkan tidak adanya pengaruh antara keduanya adalah analisis cross-sectional pada 859 pria dan wanita yang melaporkan hubungan kebalikan sederhana antara intake EPA dan DHA dengan kadar CRP. ${ }^{12}$ Selain itu pada individu obesitas, $4 \mathrm{~g}$ /hari minyak ikan selama 6 minggu juga tidak menurunkan kadar CRP. ${ }^{13}$ Penelitian tahun 2003 pada individu sehat dengan usia rata-rata 38 tahun yang memiliki kadar CRP rendah (median $0.78 \mathrm{mg} / \mathrm{L}$ ) menyebutkan tidak ada efek asam lemak omega-3 terhadap CRP. ${ }^{14}$

Sejalan dengan penelitian cross-sectional, penelitian prospektif juga menunjukkan hasil yang sama. Beberapa penelitian mengevaluasi efek dari minyak ikan dan omega-3 dari tumbuhan ALA terhadap kadar CRP. ${ }^{15-17}$ Penelitian yang mengevaluasi suplemen minyak ikan dalam berbagai dosis, penelitian dengan "Mediterranean diet", dan penelitian dengan ALA pada diet menunjukkan rendahnya kualitas pada rentang penggunaan. Bagaimanapun, semua penelitian tersebut menyatakan tidak adanya perubahan yang signifikan pada kadar CRP dengan konsumsi asam lemak omega-3.

Pengaruh asupan asam lemak omega-3 terhadap kadar CRP masih kontroversial, karena selain penelitian dengan hasil yang menunjukkan tidak adanya pengaruh asupan asam lemak omega3 terhadap kadar CRP, terdapat pula penelitian yang menunjukkan adanya pengaruh asupan asam lemak omega-3 terhadap kadar CRP, baik yang melalui asupan asam lemak omega-3 secara langsung maupun prediktor asupan asam lemak omega-3 atau indeks omega-3. Penelitian pada subjek yang mengalami peningkatan kadar CRP ( $\geq 3 \mathrm{mg} / \mathrm{L}$ ) yang diberikan treatment asam lemak omega-3 selama 8 minggu menunjukkan presentase kadar CRP menurun signifikan sedangkan tidak pada kelompok placebo. ${ }^{18}$

Penelitian cross-sectional pada orang Haitan Amerika dan Afrika Amerika dengan atau tanpa diabetes melitus tipe 2 menunjukkan etnis yang mengonsumsi asam lemak omega-3 lebih rendah memiliki kadar CRP yang 3 kali lebih tinggi. ${ }^{19}$ Penelitian tahun 2007 pada subjek pasien hemodialisa yang diberikan suplementasi EPA+DHA dengan rasio 2:1 sebanyak $1.3 \mathrm{~g}$ setiap hari menghasilkan peningkatan kadar asam lemak omega-3 dalam darah atau indeks omega-3 dan penurunan kadar CRP yang signifikan. ${ }^{20}$

Selain penelitian pada subjek penderita suatu penyakit dan penelitian yang meneliti penurunan kadar CRP melalui prediktor asupan asam lemak omega-3, penelitian lain pada subjek sehat dan melalui konsumsi langsung asam lemak omega-3 juga telah dilakukan. Penelitian tersebut menginvestigasi efek konsumsi ikan terhadap kadar CRP. Pada subjek sehat yang mengonsumsi ikan sebanyak $>300$ g per minggu, rata-rata memiliki kadar CRP yang 33\% lebih rendah, bahkan pada subjek yang mengonsumsi ikan dengan kuantitas yang lebih sedikit yaitu 150-300 g per minggu juga menunjukkan hasil serupa yang signifikan. ${ }^{21}$

Pada penelitian ini, beberapa kemungkinan yang dicurigai menyebabkan hipotesis tidak tebukti adalah pakan yang diberikan pada tikus tidak selalu dihabiskan, diketahui dari rata-rata sisa pakan selama 19 hari yang dapat dilihat pada gambar 3 . Kemudian terjadi penurunan berat badan tikus berdasarkan penimbangan berat badan pada sebelum dan setelah perlakuan yang dapat dilihat pada gambar 2. Selain itu, ikan teri yang digunakan untuk peneitian tidak dilakukan pengujian kandungan gizi terlebih dahulu terutama kandungan asam lemak omega-3. Kandungan gizi ikan teri hanya diketahui berdasarkan literatur, sehingga kemungkinan kandungan asam lemak omega-3 pada ikan teri yang digunakan dapat berbeda dengan literatur yang menyebutkan kandungan asam lemak omega-3 ikan teri (Engraulis encrasicolus) yaitu 1.4 g per $100 \mathrm{~g}^{7}$

Selain beberapa kemungkinan bias pada saat intervensi, pemilihan metode pengukuran kadar CRP juga dapat menjadi salah satu faktor tidak terbuktinya hipotesis. Pengukuran kadar CRP pada penelitian ini menggunakan metode CRP kuantitatif, yang ternyata tidak dapat menunjukkan hasil secara spesifik. Metode CRP kuantitatif hanya dapat menunjukkan batas $<5 \mathrm{mg} / \mathrm{L}$ yang berarti normal dan $>5 \mathrm{mg} / \mathrm{L}$ yang berarti tinggi, hal ini karena reagent yang digunakan sensitifitasnya hanya dapat membaca hingga batas tersebut. Selain itu alat laboratorium tidak mampu membaca kadar CRP dari hewan coba secara spesifik karena ukurannya yang kecil sehingga alat tidak sensitif membaca kadar CRP yang jumlahnya terlalu sedikit. ${ }^{22}$ Berbeda dengan CRP kuantitatif, metode High-sensitivity CRP (HS-CRP) dapat membaca kadar CRP hingga $<1.0 \mathrm{mg} / \mathrm{L}$. Namun, tidak semua laboratorium dapat melakukan pengukuran kadar CRP dari darah hewan coba dengan metode HSCRP, karena metode ini utamanya diperuntukkan untuk mengukur kadar CRP manusia. Apabila pada penelitian ini dapat menggunakan metode HS-CRP, kemungkinan hasil kadar CRP subjek tidak akan seluruhnya sama, sehingga data yang diperoleh dapat diuji secara statistik. 


\section{SIMPULAN}

Data yang diperoleh pada penelitian ini tidak dapat digunakan untuk menjelaskan mekanisme protektif PKV dari diet tinggi asam lemak omega-3 yang berasal dari ikan teri terhadap kadar CRP tikus sehat.

\section{SARAN}

Lakukan pengujian kadar CRP dengan metode HS-CRP agar didapatkan hasil yang lebih spesifik. Penelitian lebih lanjut pada tikus dengan penyakit kardiovaskuler perlu dilakukan.

\section{DAFTAR PUSTAKA}

1. Kones R.The Jupiter study, CRP screening, and aggressive statin therapy-implications for the primary prevention of cardiovascular disease. Ther Adv Cardiovasc Dis. 2009;3:09-315

2. Ridker PM, Danielson E, Fonseca FA, Genest J, Gotto AM Jr.Rosuvastain to prevent vascular events in men and women with elevated C-reactive protein. N Engl J Med. 2008;359:2195-2207

3. Shishehbor MH, Deepak DO, Bhatt DL, Topol Eric J.Using C-reactive protein to assess cardiovascular disease risk. Cleveland Clinic Journal of Medicine. 2003;70:7

4. Pearson TA, Mensah GA, Alexander RW, Anderson JL, Cannon RM.Markers of Inflammation and Cardiovascular Disease: Application to Clinical and Public Health Practice: A Statement for Healthcare Professionals From the Centers for Disease Control and Prevention and the American Heart Association. Circulation. 2003;107:499-511

5. Kalogeropoulos N, Panagiotakos DB, Pitsavos C, Chrysohoou C, Rousinou G, Toutouza M. Unsaturated fatty acids are inversely associated and n-6/n-3 ratios are positively related to inflammation and coagulation markers in plasma of apparently healthy adults. Clin Chim Acta. 2010;411:584-591

6. Muhammad Kamran I, Morledge Thomas, Sachar Ravish, Zeldin Annette, Wolski Kathy, Bhatt DL.Treatment with $\omega-3$ fatty acids reduces serum Creactive protein concentration.2011;42:120-126

7. Exler J.Composition of foods: Finfish and Shellfish Products. Agriculture Handbook Washington, DC, USDA. 1987;8-15

8. Overview of the world's anchovy sector and trade possibilities for Georgian anchovy products. Eurofish International Organisation.2012

9. Kučera O, Garnol T, Lotkov H, Stnkov P, Mazurov Y, Hroch M.The Effect of Rat Strain, Diet Composition and Feeding Period on The Development of a Nutritional Model of NonAlcoholic Fatty Liver Disease in Rats. Journal of Physiological Research. 2011;60:317-328

10. Dahlan, Sopiyudin. Statistika Untuk Kedokteran dan Kesehatan. Penerbit Salemba. 2004;122-124

11. A Geelen, A Brouwer, EG Schouten, C Kluft, MB Katan, PL Zock. Intake of n-3 fatty acids from fish does not lower serum concentrations of C-reactive protein in healthy subjects. European Journal of Clinical Nutrition. 2004;58:1440-1442

12. Pischon T, Hankinson SE, Hotamisligil GS, Rifai N, Willett WC, dan Rimm EB. Habitual dietary intake of n-3 and n-6 fatty acids in relation to inflammatory markers among US men and women.Circulation. 2003;108:155-160

13. Chan DC, Watts GF, Barrett PH, Beilin LJ, Mori TA. Effect of atorvastatin and fish oil on plasma highsensitivity C-reactive protein concentrations in individuals with visceral obesity. Clin Chem. 2002;48:877-883

14. Madsen T, Christensen JH, Blom M, Schmidt EB. The effect of dietary n-3 fatty acids on serum concentrations of C-reactive protein: a dose-response study. Br J Nutr. 2003;89:517-522

15. Blok WL, Deslypere JP, Demacker PN, van der VenJongekrijg J, Hectors MP, van der Meer JW, Katan MB. Pro- and anti-inflammatory cytokines in healthy volunteers fed various doses of fish oil for 1 year. Eur J Clin Invest. 1997;27:1003-1008

16. Mezzano D, Leighton F, Martinez C, Marshall G, Cuevas A, Castillo O. Complementary effects of Mediterranean diet and moderate red wine intake on haemostatic cardiovascular risk factors. Eur J Clin Nutr 2001;55:444-451

17. Junker R, Kratz M, Neufeld M, Erren M, Nofer JR, Schulte H. Effects of diets containing olive oil, sunflower oil, or rapeseed oil on the hemostatic system. Thromb Haemost 2001;85:280-286

18. Kamran I Muhammad, Thomas Morledge, Ravish Sachar, Annette Zeldin, Kathy Wolski. Treatment with $\omega-3$ fatty acids reduces serum C-reactive protein concentration. Clinical lipidology. 2011;6:6:723-729

19. Huffman Fatma G, Vaccaro Joan A, Exebio Joel C, Ajabshir Sahar, Zarini Gustavo G, Shaban Lemia H. Relationship of Omega-3 Fatty Acids on C-Reactive Protein and Homocysteine in Haitian and African Americans with and without Type 2 Diabetes. J Nutr Food Sci 2013;3:1

20. Saifullah Akber, Watkins BA, Saha C, Y Li, Moe SM, Friedman AN. Oral fish oil supplementation raises blood omega-3 levels and lowers C-reactive protein in haemodialysis patients - a pilot study. Nephrol Dial Transplant 2007; doi:10.1093/ndt/gfm422

21. Zampelas A, Panagiotakos DB, Pitsavos C, Das UN, Chrysohoou C, Skoumas Y. Fish consumption among heathy adults is associated with decrease levels of inflammatory markers related to cardiovascular disease : the ATTICA study. J Am Coll Cardiol. 2005;46(1):120-124

22. Pepys, Mark B, Hirschfield, Gideon M. C-reactive protein: a critical update. $\mathrm{J}$ Clin Invest. 2003;111:1805-1812 